\title{
Metabolites with Nematicidal and Antimicrobial Activities from the Ascomycete Lachnum papyraceum (Karst.) Karst \\ V. Production, Isolation and Biological Activities of Bromine-containing Mycorrhizin and Lachnumon Derivatives and Four Additional New Bioactive Metabolites
}

\author{
Marc STADler and HeIdrun ANKE* \\ Universität Kaiserslautern, Lehrbereich Biotechnologie, \\ D-67663 Kaiserslautern, Fed. Rep. Germany

\section{OLOV STERNER} \\ Department of Organic Chemistry 2, University of Lund, \\ POB 124, S-221 00 Lund, Sweden
}

(Received for publication July 29, 1994)

\begin{abstract}
Eight novel bioactive metabolites were isolated from submerged cultures of the ascomycete Lachnum papyraceum (Karst.) Karst, when $\mathrm{CaBr}_{2}$ was added to the cultures after the onset of secondary metabolism. Four of these metabolites $(16 \sim 19)$ are bromo analogues of mycorrhizin $A$ and lachnumon, while ( $\left(1^{\prime} Z\right)$-dechloromycorrhizin A (12) and the papyracons A (13), B (14), and C (15) are non-halogenated compounds structurally related to the mycorrhizins. All compounds exhibited antimicrobial, cytotoxic, nematicidal and phytotoxic activities. The brominated mycorrhizins and lachnumons were found to be slightly less active than the chlorine-containing compounds. All mycorrhizin derivatives were mutagenic in the Ames test, suggesting DNA-alkylating properties.
\end{abstract}

During investigations on the secondary metabolism of the ascomycete Lachnum papyraceum, several novel chlorinated and brominated isocoumarin derivatives were obtained when the fungus was cultured in $\mathrm{CaBr}_{2}-$ containing medium. But no bromo analogues of chlorine-containing lachnumon (1) or mycorrhizin A (3) were detected, instead the biosynthesis of these compounds was suppressed $^{1 \sim 4)}$. As previous studies have indicated that the halogenation occurs during the final steps of the mycorrhizin biosynthesis, and that dechloromycorrhizin A (5) might be a substrate for halogenation ${ }^{3)}$, it appeared logical to add bromide at a later stage of the fermentation when the production of $\mathbf{5}$ already had started.

In this paper we describe the production, isolation and biological activities of four new brominated metabolites and four novel non-halogenated antibiotics. The compounds were obtained from fermentations of L. papyraceum when $\mathrm{CaBr}_{2}$ was added to the culture after the onset of secondary metabolism. The structural elucidation of the eight new compounds will be the subject of the two following papers ${ }^{5,6)}$.

\section{Materials and Methods}

General

Materials and methods for fermentation of $L . p a$ - pyraceum, detection and isolation of bioactive compounds have been previously reported in papers of this series $^{1,3)}$.

\section{Biological Assays}

Methods for determination of nematicidal, antimicrobial, and cytotoxic activities and the preparation of cysteine adducts have been previously described ${ }^{3}$. The Ames test was carried out as a "pour plate test" without S9 $\mathrm{mix}^{7}$, using different strains of Salmonella typhimurium. Test plates (diameter $5 \mathrm{~cm}$ ) with $1 \mathrm{ml}$ of top agar on $5 \mathrm{ml}$ of Vogel Bonner medium were used. The experiments were repeated three times with each concentration in triplicate.

\section{Fermentation of L. papyraceum}

The fermentation, preparation of extracts and the determination of biological activities were carried out as described previously ${ }^{3}$. The production of secondary metabolites was followed by analytical HPLC ${ }^{3)}$. Fermentations were carried out in MGP medium ${ }^{3)}, \mathrm{CaBr}_{2}$ was added after dechloromycorrhizin A (5) could be detected in extracts of the culture filtrate.

Isolation of Compounds $12 \sim 19$

The culture fluid (18 liters) obtained by filtration was applied onto HP 21 resin $(1.2 \mathrm{~kg})$, which was eluted with 3 liters of acetone, followed by evaporation of the ace- 
Fig. 1. Structures of compounds $1 \sim 19$ produced by L. papyraceum.<smiles>[R]C1=C[C@@H](OC)[C@@H](O)[C@@]2(/C(Cl)=C/C)O[C@]12Cl</smiles>

1: $\mathrm{R}=\mathrm{O}$

2: $\mathrm{R}=\mathrm{OH}, \mathrm{H}$<smiles>[R]C(=CC)C1=C([R])C(=O)[C@]2(O)OC(C)(C)CC[C@H]2C1=O</smiles>

3: $\mathrm{R}_{1}=\mathrm{H}, \mathrm{R}_{2}=\mathrm{Cl}$

4: $\mathrm{R}_{1}=\mathrm{R}_{2}=\mathrm{Cl}$

5: $\mathrm{R}_{1}=\mathrm{R}_{2}=\mathrm{H}$<smiles>[R20]c1cc(O)c2c(c1[R])[C@H]([Z2])[C@H](C)OC2=O</smiles>

6: $R=R^{\prime}=R^{\prime \prime}=H$

7: $\mathrm{R}=\mathrm{R}^{\prime}=\mathrm{H}, \mathrm{R} \mathrm{R}^{\prime \prime}=\mathrm{Cl}$

8: $\mathrm{R}=\mathrm{R}^{\prime}=\mathrm{H}, \mathrm{R}^{\prime \prime}=\mathrm{Br}$

9: $\mathrm{R}=\mathrm{CH}_{3}, \mathrm{R}^{\prime}=\mathrm{R}^{\prime \prime}=\mathrm{H}$

10: $\mathrm{R}=\mathrm{CH}_{3}, \mathrm{R}^{\prime}=\mathrm{H}, \mathrm{R}^{\prime \prime}=\mathrm{Cl}$

11: $\mathrm{R}=\mathrm{H}, \mathrm{R}^{\prime}=\mathrm{OH}, \mathrm{R}^{\prime \prime}=\mathrm{Cl}$<smiles>C/C=C\C1=CC(=O)[C@@]23CCC(C)(C)O[C@]2(O)C(=O)C13</smiles>

12<smiles>CC(=O)/C=C1\C[C@@H](O)[C@@]23C[C@H](C)[C@](C)(O[C@]2(O)C1=O)O3</smiles>

13

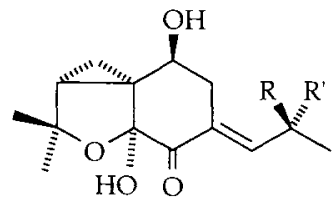

14: $\mathrm{R}=\mathrm{OH}, \mathrm{R}^{\prime}=\mathrm{H}$ 15: $\mathrm{R}=\mathrm{H}, \mathrm{R}^{\prime}=\mathrm{OH}$<smiles>[R]C12OC1(C(Br)=CC)C(O)C(OC)=CC2=O</smiles>

16: $\mathrm{R}=\mathrm{H}$ 17: $\mathrm{R}=\mathrm{Cl}$

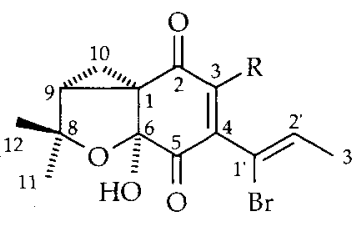

18: $\mathrm{R}=\mathrm{H}$

19: $\mathrm{R}=\mathrm{Cl}$

$\mathbf{1}=$ Lachnumon, $\mathbf{2}$ = lachnumol A, 3=mycorrhizin A, 4=chloromycorrhizin $\mathrm{A}, \mathbf{5}=\left(1^{\prime} E\right)$-dechloromycorrhizin A, 6=6-hydroxymellein, 7=4-chloro-6-hydroxymellein, 8=4-bromo-6-hydroxymellein, 9=6methoxymellein, $\mathbf{1 0}=4$-chloro-6-methoxymellein, $11=4$-chloro-6,7-dihydroxymellein, $12=\left(1^{\prime} Z\right)$-dechloromycorrhizin $A, \mathbf{1 3}=$ papyracon $A, \mathbf{1 4}=$ papyracon $B, 15=$ papyracon $C, \mathbf{1 6}=$ lachnumon $B 1, \mathbf{1 7}=$ lachnumon $B 2$, $\mathbf{1 8}=$ mycorrhizin $\mathrm{B} 1, \mathbf{1 9}=$ mycorrhizin $\mathrm{B} 2$.

tone in vacuo and extraction of the remaining aqueous phase with $3 \times 500 \mathrm{ml}$ ethyl acetate. The combined ethyl acetate extracts were dried with $\mathrm{Na}_{2} \mathrm{SO}_{4}$ and evaporated to an oily residue $(7.8 \mathrm{~g})$. This crude extract was separated into five intermediate products by flash chromatography on silica gel 60 (column size: $4 \mathrm{~cm} \times 20 \mathrm{~cm}$ ), using a cyclohexane - ethyl acetate gradient.

Intermediate product $1(237 \mathrm{mg})$ was eluted with 1 liter cyclohexane - ethyl acetate $(8: 2)$. HPLC on LiChroPrep Diol (cyclohexane - $t$-butyl methyl ether; 7:3) led to the isolation of $57 \mathrm{mg}$ dechloromycorrhizin A (5), $34 \mathrm{mg}$ of ( $1^{\prime} Z$ )-dechloromycorrhizin A (12), $59 \mathrm{mg}$ of intermediate product 1a, and $54 \mathrm{mg}$ of intermediate product $1 \mathrm{~b}$. Each of these intermediate products was subjected to HPLC on LiChroGel PS1 $(10 \mu \mathrm{m})$ in 2-propanol, yielding $34 \mathrm{mg}$ of mycorrhizin A (3) and $9 \mathrm{mg}$ of mycorrhizin B1 (18) from intermediate product la. From intermediate product $1 \mathrm{~b}, 33 \mathrm{mg}$ of chloromycorrhizin A (4) and $14 \mathrm{mg}$ of mycorrhizin B2 (19) were obtained.

From $490 \mathrm{mg}$ of intermediate product 2 (obtained by elution with cyclohexane-ethyl acetate; $7: 3)$, the isocoumarin derivatives $6(34 \mathrm{mg}), 7(29 \mathrm{mg})$, and $8(53 \mathrm{mg})$ were obtained by a similar isolation procedure as described previously" ${ }^{11}$.

The intermediate products $3 \sim 5$ were eluted subsequently from the column. Elution with 1 liter cyclohexane-ethyl acetate $(1: 1)$ resulted in intermediate product $3(360 \mathrm{mg})$, which was further purified on LiChroPrep Diol with cyclohexane - $t$-butyl methyl ether $(1: 1)$, yielding $11 \mathrm{mg}$ of lachnumon B1 (16) and intermediate product $3 \mathrm{a}(145 \mathrm{mg})$. From intermediate product $3 \mathrm{a}$, lachnumon $(1 ; 89 \mathrm{mg})$ and lachnumon B2 $(17 ; 11 \mathrm{mg})$ were isolated by repetitive HPLC on LiChroGel PS1 in 2-propanol.

Intermediate product $4(240 \mathrm{mg})$ was obtained at 500 $\mathrm{ml}$ cyclohexane-ethyl acetate $(1: 2)$ and yielded $41 \mathrm{mg}$ of lachnumol A (1) and $41 \mathrm{mg}$ of papyracon A (13) after HPLC on LiChroSorb CN (cyclohexane - ethyl acetate; $1: 1)$.

Intermediate product $5(140 \mathrm{mg})$ was eluted with additional $500 \mathrm{ml}$ cyclohexane - ethyl acetate $(1: 2)$. HPLC on LiChroGel PS1 in 2-propanol yielded a two-component mixture (intermediate product $5 \mathrm{a}$ ), from which the stereoisomers, papyracons $B(14 ; 20 \mathrm{mg})$ and $C(15$; $25 \mathrm{mg}$ ) were separated by HPLC on LiChroSorb Diol ( $t$-butyl methyl ether-2-propanol; 9:1).

\section{Results and Discussion}

\section{Fermentation of L. papyraceum}

During the fermentation, dechloromycorrhizin A (5) was detected in extracts of the culture broth after ten days and subsequently $\mathrm{CaBr}_{2}(50 \mathrm{mM})$ was added. The addition of $\mathrm{CaBr}_{2}$ had no influence on the production of fungal biomass. The biological activities of extracts were only slightly weaker as compared to extracts from bromide-free MGP medium ${ }^{3)}$ but much higher as compared to fermentations with $\mathrm{CaBr}_{2}$ added at the beginning ${ }^{1)}$. The composition of the extracts, however, changed after the bromide salt had been added. Beside 6- 
hydroxymellein (6), its 4-chloro- and 4-bromo-derivatives (7 and 8), two new peaks corresponding to compounds 18 and 19, with UV spectra similar to those of compounds 3 and 4 , were detected by HPLC analysis (the spectroscopic data of the new compounds are given in the following paper). In comparison to the chlorinated mycorrhizins, compounds 18 and 19 showed slightly higher retention times on reversed phase materials, suggesting an increased lipophilicity of the new products. This indicated that bromide and not chloride might have been incorporated into dechloromycorrhizin.

HPLC analysis of the intermediate products $3 \sim 5$ revealed the presence of additional metabolites with lachnumon-like UV spectra. In the crude extracts these compounds were hardly detectable, as their concentrations were below $1 \mathrm{mg} /$ liter. They were isolated in small amounts and structural elucidation ${ }^{5,6)}$ showed that two of these metabolites (16 and 17) are bromo analogues of lachnumon. Three metabolites $(\mathbf{1 3} \sim \mathbf{1 5})$ had the same carbon skeleton as the mycorrhizins but were named papyracon $\mathrm{A}, \mathrm{B}$, and $\mathrm{C}$, as they differ significantly from the mycorrhizins.

In comparison to the fermentation when $\mathrm{CaBr}_{2}$ was added at the beginning ${ }^{1)}$, the total amount of secondary metabolites was similar, e.g. $535 \mathrm{mg}$ from a 20 -liter fermentor in this study and $575 \mathrm{mg}$ in the previous one ${ }^{11}$. However, the yields of halogenated isocoumarin derivatives $(7$ and 8 ) were considerably lower here $(82 \mathrm{mg}$ compared to $476 \mathrm{mg}$ ), and there were no traces of compound $9 \sim 11$. Compound 12 was also present in extracts from bromide-free MGP medium ${ }^{3)}$ but due to its instability, the isolation and structural elucidation of $\mathbf{1 2}$ could not be completed earlier and is therefore reported here and in the following paper.

So far, all brominated fungal metabolites were obtained as the bromo analogues of chlorine-containing metabolites $^{8 \sim 12)}$, and their production in significant amounts under natural conditions does not seem very likely. The ecological importance of chlorinated fungal metabolites was recently examplified by the role that chlorinated anisyl alcohols and aldehydes play during both lignin and forest litter degradation ${ }^{13)}$.

Biological Activities of Compounds $12 \sim 19$

The nematicidal effects of $12 \sim 19$ listed in Table 1 show that Caenorhabditis elegans is sensitive to all compounds, the new mycorrhizins 12, 18, and 19 being the most potent ones. Compared to the chlorinated compounds ( 3 and $\mathbf{4}$ ), the brominated analogues were slightly less active. The same is true for lachnumon B2.(17) and lachnumon (1).

In the agar diffusion assay (Table 2), Penicillium notatum, Paecilomyces variotii and Mucor miehei were inhibited by the new mycorrhizins $(\mathbf{1 2}, \mathbf{1 8}$, and 19). Only $P$. notatum was inhibited by $13, \mathbf{1 6}$, and 17 . In the serial dilution assay (Table 3), rather weak antimicrobial activities towards bacteria and yeasts were found for $13 \sim 17$, whereas the activities of 12,18 , and 19 were similar to those of the mycorrhizins $3 \sim \mathbf{5}^{3)}$. As shown in Table 4, compounds 12, 13, 18, and 19 showed cytotoxic effects, whereas the activities of $\mathbf{1 4} \sim \mathbf{1 7}$ only were weak. In addition, 12 19 had weak phytotoxic effects on the growth of Setaria italica and Lepidium sativum (data not shown). Compounds 12, 13, 18, and 19 reacted with L-cysteine, forming ninhydrin-positive adducts which were devoid of biological activities. The mutagenic ac-

Table 1. Nematicidal activities of compounds 1, 3 5 and $12 \sim 19$ towards Caenorhabditis elegans.

\begin{tabular}{cc}
\hline Compound & $\mathrm{ND}_{90}(\mu \mathrm{g} / \mathrm{ml})$ \\
\hline 1 & $25 \sim 50$ \\
3 & $1 \sim 2$ \\
4 & 5 \\
5 & 5 \\
12 & 5 \\
13 & 25 \\
14 & 100 \\
15 & 100 \\
16 & 25 \\
17 & 50 \\
18 & 5 \\
19 & 10 \\
Ivermectin & 0.1
\end{tabular}

$\mathrm{ND}_{90}$ : Concentrations causing more than $90 \%$ immotility after 18 hours.

Table 2. Antifungal activity of compounds $1,3 \sim 5$ and $12 \sim 19$ in the agar diffusion assay after 24 hours with $50 \mu \mathrm{g} /$ paper disk $(6 \mathrm{~mm}) .14$ and 15 were inactive.

\begin{tabular}{lcccccccccc}
\hline \multirow{2}{*}{ Organism } & \multicolumn{10}{c}{ Diameter of inhibition zone (mm) } \\
\cline { 2 - 10 } & $\mathbf{1}$ & $\mathbf{3}$ & $\mathbf{4}$ & $\mathbf{5}$ & $\mathbf{1 2}$ & $\mathbf{1 3}$ & $\mathbf{1 6}$ & $\mathbf{1 7}$ & $\mathbf{1 8}$ & $\mathbf{1 9}$ \\
\hline Mucor miehei & - & 27 & 12 & 14 & 14 & - & - & -15 & 20 & 15 \\
Penicillium notatum & 15 & 20 & 10 & 13 & 13 & 15 & 10 & 14 & 19 & 13 \\
Paecilomyces variotii & - & 19 & 13 & 12 & 12 & - & - & - & 21 & 14 \\
\hline
\end{tabular}


Table 3. Antimicrobial activities of compounds $12 \sim 19$ in the serial dilution assay.

\begin{tabular}{|c|c|c|c|c|c|c|c|c|}
\hline \multirow{2}{*}{ Organism } & \multicolumn{8}{|c|}{$\mathrm{MIC}(\mu \mathrm{g} / \mathrm{ml})$} \\
\hline & 12 & 13 & 14 & 15 & 16 & 17 & 18 & 19 \\
\hline \multicolumn{9}{|l|}{ Bacteria (Nutrient broth) } \\
\hline Acinetobacter calcoaceticus & 25 & 50 & $>100$ & $>100$ & 100 & 100 & 25 & 50 \\
\hline Bacillus brevis & 10 & 50 & 100 & 100 & 100 & 100 & 2 & 5 \\
\hline Bacillus subtilis & 10 & 50 & 100 & 100 & 100 & 100 & 2 & 10 \\
\hline Micrococcus luteus & 10 & $>100$ & 100 & 100 & $>100$ & 100 & 25 & 25 \\
\hline \multicolumn{9}{|l|}{ Yeasts (YMG medium) } \\
\hline Candida albicans & 10 & 100 & $>100$ & $>100$ & 50 & 50 & 10 & 10 \\
\hline Nematospora coryli. & 2 & 10 & 50 & 50 & 50 & 100 & 2 & 2 \\
\hline Rhodotorula glutinis & 25 & 50 & $>100$ & $>100$ & 100 & 100 & 25 & 50 \\
\hline Saccharomyces cerevisiae & 10 & $>100$ & 50 & 25 & 25 & $>100$ & 10 & 25 \\
\hline
\end{tabular}

Table 4. Cytotoxic activities of compounds $3 \sim 5$ and $12 \sim 19$ towards mammalian cell lines.

\begin{tabular}{|c|c|c|c|c|c|c|c|c|c|c|c|}
\hline \multirow{2}{*}{ Cell line } & \multicolumn{11}{|c|}{$\mathrm{IC}_{100}(\mu \mathrm{g} / \mathrm{ml})$} \\
\hline & 3 & 4 & 5 & 12 & 13 & 14 & 15 & 16 & 17 & 18 & 19 \\
\hline L 1210 & 0.1 & 0.5 & 1.0 & 2.0 & 10.0 & 50.0 & 50.0 & 50.0 & 50.0 & 2.0 & 2.0 \\
\hline HL 60 & 0.5 & 0.5 & 0.5 & 1.0 & 10.0 & 25.0 & 50.0 & 50.0 & 50.0 & 2.0 & 2.0 \\
\hline HeLa S3 & 0.5 & 2.0 & 2.0 & 2.0 & 10.0 & 100.0 & 100.0 & 25.0 & 10.0 & 2.0 & 2.0 \\
\hline BHK 21 & 1.0 & 2.0 & 2.0 & 2.0 & 10.0 & 50.0 & 50.0 & 25.0 & 10.0 & 2.0 & 10.0 \\
\hline
\end{tabular}

$\mathrm{IC}_{100}$ : Concentration causing total lysis of the cells.

Table 5. Mutagenic effects of compounds 3 5, 12, 18 and 19 towards different Salmonella typhimurium strains without metabolic activation. The response is given as the average number of revertants/plate.

\begin{tabular}{|c|c|c|c|c|c|}
\hline \multirow{2}{*}{$\begin{array}{l}\text { Com- } \\
\text { pound }\end{array}$} & \multirow{2}{*}{$\begin{array}{c}\text { Concen- } \\
\text { tration } \\
(\mu \mathrm{g} / \text { plate })\end{array}$} & \multicolumn{4}{|c|}{$\begin{array}{l}\text { Number of revertants/plate strain } \\
\text { (S. typhimurium) }\end{array}$} \\
\hline & & TA 97 & TA 98 & TA 100 & TA 102 \\
\hline None & & 90 & 19 & 61 & 32 \\
\hline 3 & 2 & 78 & 13 & 102 & 81 \\
\hline 4 & 2 & 73 & 30 & 189 & 119 \\
\hline 5 & 5 & 300 & 21 & 830 & $>5,000$ \\
\hline 12 & 5 & 150 & 17 & 1,050 & 3,200 \\
\hline 18 & 5 & 300 & 13 & 870 & 41 \\
\hline 19 & 5 & 210 & 26 & 260 & 110 \\
\hline \multicolumn{2}{|c|}{$\begin{array}{l}\text { Daunomycin } \\
(2 \mu \mathrm{g} / \text { plate })\end{array}$} & $>5,000$ & 3,500 & 90 & 1,800 \\
\hline \multicolumn{2}{|c|}{$\operatorname{MES}(2 \mu \mathrm{l} /$ plate $)$} & 117 & 112 & $>5,000$ & $>5,000$ \\
\hline
\end{tabular}

tivities of the mycorrhizins (Table 5) indicate the biomolecule-alkylating potency of these compounds. Strains suitable for the detection of base pair mutations showed a significant response, whereas the "frame shift strains" S. typhimurium TA 98 and TA 97 were not or less sensitive. The highest responses were obtained with the two dechloromycorrhizin A isomers (5 and 12). Papyracon A (13) inhibited growth of all Salmonella strains at $25 \mu \mathrm{g} /$ plate, but was not mutagenic, neither were compounds 1, 2, 7 11, 14 17. The influence of microsomal activation remains to be investigated.
Compounds 14, 15, and 16 did not inhibit the aggregation of bovine thrombocytes ${ }^{14)}$ at $132 \mu \mathrm{g} / \mathrm{ml}, \mathbf{1 2}$, 13, 18, and 19 were active at $33 \mu \mathrm{g} / \mathrm{ml}$ and lachnumon B2 (17) at $66 \mu \mathrm{g} / \mathrm{ml}$.

The biological activities of $\left(1^{\prime} Z\right)$-dechloromycorrhizin A (12) resembled those of its $\left(1^{\prime} E\right)$-isomer 5 in most biological assays. The biological effects of 16 and 17 were similar to those of lachnumon (1). Papyracon A (13) was more active than its corresponding alcohols (14 and 15).

The brominated mycorrhizins showed weaker activities than their chlorinated analogues. During studies on the reactivity of 3 to 18 with thiols, mycorrhizin B1 (18) reacted slowly, whereas mycorrhizin A (3) lost its activity immediately and was hardly detectable after 5 seconds. Similar results were obtained with chloromycorrhizin A (4) and its bromo analogue 19.

Generally, changes in the biological activities following the substitution of chlorine by bromine are difficult to predict. Brominated pyrrolomycins showed higher antimicrobial effects in comparison to their parent (chlorinated) compounds ${ }^{15,16)}$ while ten-fold weaker effects were observed in the case of the pyrrolnitrins ${ }^{17}$. Brominated rebeccamycins showed antitumor activities similar to their chloro analogues ${ }^{18}$, whereas the brominecontaining duocarmycins showed higher toxicity in mice and were more active towards tumor cells ${ }^{19)}$.

Mycorrhizins or lachnumons containing two bromine 
substitutions were not yet detected and it will be a challenge to find suitable conditions for the production of such compounds as well as to obtain metabolites containing fluorine or iodine, which up to now have never been reported as secondary metabolites in fungi ${ }^{20,21)}$.

\section{Acknowledgments}

We are grateful to the Studienstiftung des deutschen Volkes, Bonn/FRG, for financial support of our work. We thank Dr. HINDERMAYR and Dr. HANSSKE, Boehringer Mannheim, for the interpretation of the mass spectra of compounds $\mathbf{1 8}$ and $\mathbf{1 9}$.

\section{References}

1) Stadler, M; H. Anke \& O. Sterner: Metabolites with nematicidal and antimicrobial activities from the ascomycete Lachnum papyraceum (Karst.) Karst. III. Production of novel isocoumarin derivatives, isolation, and biological activities. J. Antibiotics 48 (3): 1995

2) Stadler, M.; H. Anke \& O. STERnER: New metabolites with nematicidal and antimicrobial activities from the ascomycete Lachnum papyraceum (Karst.) Karst. IV. Structural elucidation of novel isocoumarin derivatives. J. Antibiotics 48 (3): 1995

3) Stadler, M.; H. Anke, W. R. Arendholz, F. Hansske, U. ANDERs, O. STERner \& K. E. BERGQUist: Lachnumon and lachnumol $\mathrm{A}$, new metabolites with nematicidal and antimicrobial activities from the ascomycete Lachnum papyraceum (Karst.) Karst. I. Producing organism, fermentation, isolation and biological activities. J. Antibiotics 46: $961 \sim 967,1993$

4) Stadler, M.; H. Anke, O. Sterner \& K. E. Bergquist: Lachnumon and lachnumol A, new metabolites with nematicidal and antimicrobial activities from the ascomycete Lachnum papyraceum (Karst.) Karst. II. Structural elucidation. J. Antibiotics 46: 968 972, 1993

5) Stadler, M.; H. Anke, R. Shan \& O. Sterner: New metabolites with nematicidal and antimicrobial activities from the ascomycete Lachnum papyraceum (Karst.) Karst. VI. Structure determination of non-halogenated metabolites structurally related to mycorrhizin A. J. Antibiotics 48: $154 \sim 157,1995$

6) Stadler, M.; H. Anke \& O. Sterner: New metabolites with nematicidal and antimicrobial activities from the ascomycete Lachnum papyraceum (Karst.) Karst. VII. Structure determination of brominated lachnumon and mycorrhizin A derivatives. J. Antibiotics 48: 158 161, 1995

7) AmEs, B. N.; J. MCCANN \& R. YAMASAKI: Methods for detecting carcinogens and mutagens in the Salmonellal mammalian microsome mutagenicity test. Mut. Res. 31:
$347 \sim 364,1978$

8) Sakata, K.; M. Maruyama, T. Kuwatsuka, J. Uzawa, A. Sakurai, H. S. M. Lu \& J. Clardy: Structure of aspirochlorine, a novel epithiopiperazine-2,5-dione and related compounds produced by Aspergillus spp. Tennen Yuki Kogabutsu Toronkai Koen Yoshishu 29: 684 691, 1987

9) Aldridge, D. C.; A. Borrow, R. G. Forster, M. S. LARGe, H. SPEnCER \& W. B. Turner: Metabolites of Nectria coccinea. J. Chem. Soc. Perkin Trans. 1: 2136 2141, 1972

10) KACHI, H.; H. HATTORI \& T. SASSA: An antifungal substance, bromomonicillin, and its precursor produced by Monilinia fructicola. J. Antibiotics 39: 164 165, 1986

11) GRIBble, G. W.: Naturally occurring organohalogen compounds, a survey. J. Nat. Prod. 55: 1353 1395, 1992

12) Patterson, E. L.; W. W. Andres \& L. A. Mitschler: Isolation of the bromo analogue of caldariomycin from Caldariomyces fumago. Appl. Microbiol. 15: 528 530, 1967

13) De Jong, E.; J. A. Field, H. E. Spinnler, J. B. P. A. WiJnBerg \& J. A. M. DE BonT: Significant biogenesis of chlorinated aromatics by fungi in natural environments. Appl. Environ. Microbiol. 60: 264 270, 1994

14) Lorenzen, K.; T. Anke, U. Anders, H. Hindermayr \& F. HANSSKE: Two inhibitors of platelet aggregation from a Panus species (Basidiomycetes), Z. Naturforsch. 49c: $132 \sim 138,1994$

15) Ezaki, N.; T. Shomura, M. Koyama, T. Niwa, M. Kojima, S. Inouye, T. Ito \& T. Ninda: New chlorinated nitro-pyrrole antibiotics, pyrrolomycins A and B (SF-2080 A and B). J. Antibiotics 34: 1363 1365, 1981

16) Ezaki, N.; M. Koyama, Y. Kodama, T. Shomura, K. TAShiro, T. Tsuruoka \& S. InOUYE: Pyrrolomycins F1, F2a, F2b and F3, new metabolites produced by the addition of bromide to the fermentation. J. Antibiotics 36: $1431 \sim 1438,1983$

17) Ajisaka, M.; K. Kariyone, K. Jomon, H. Yazawa \& K. ARIWA: Isolation of the bromo analogues of pyrrolnitrin from Pseudomonas pyrrolnitrica. Agric. Biol. Chem. 33: $557 \sim 564,1983$

18) LAM, K. S.; R. D. SChroeder, J. M. Veitch, J. A. Matson \& S. FORENZA: Isolation of a bromo analog of rebeccamycin from Saccharothrix aerocolonigens. J. Antibiotics 44: $934 \sim 939,1991$

19) OGawa, T.; M. Ichimura, S. Katsumata, M. Morimoto \& K. TAKAHASHI: New antitumor antibiotics, duocarmycins B1 and B2. J. Antibiotics 42: $1299 \sim 1301,1989$

20) Neidleman, S. L. \& J. Geigert: Biohalogenation. Ellis Harwood Ltd. Chichester/UK 1986, p. 13 15

21) Berdy Bioactive Natural Products Database. Update 1/1994 Szenzor Budapest, Hungary 1994 